\section{Effects of various illicit drugs on immune capacity of blue mussel (Mytilus edulis)}

\author{
C. Brousseau-Fournier, ${ }^{1-3}$ C. Côté,,$^{1-3}$ \\ P. Pharand,1-3 J.P. Gagné,, 2,3 \\ A. Lajeunesse, ${ }^{4}$ M. Fournier, ${ }^{1,3}$ \\ P. Brousseau ${ }^{1,3}$ \\ ${ }^{1}$ Parc de la rivière Mitis, Ste-Flavie; \\ 2UQAR, Rimouski; ${ }^{3}$ ISMER-UQAR, \\ Rimouski; ' ${ }^{U Q T R}$, Trois-Rivières, \\ Québec, Canada
}

\section{Introduction}

Illicit drugs, which are recognized as emerging pollutants, are present in important quantity in the marine environment due to the human consumption. ${ }^{1}$ The content, which defines illicit drugs, is the fact that they have been declared illegal by international drugs treaties, unless they are for medical usage because they may lead the consumer to have an addiction problem., ${ }^{1,2}$ The concentrations found in the environment are in a range of $\mathrm{ng} / \mathrm{L}$ to $\mu \mathrm{g} / \mathrm{L}$ though, near wastewater treatment plants and production facilities the concentrations are the highest. ${ }^{2,3}$ Indeed so far, little information is available on the effect that these drugs can cause on the marine organisms exposed to them. They might have important effect even at very low concentrations on structure of aquatic communities and on the behavior of organisms..$^{48}$ In this study, we looked at the impact of four illicit drugs as well as a mixture on the immune system of the blue mussel.

\section{Materials and Methods}

\section{Test system}

Blue mussels (Mytilus edulis) were collected in Mitis Bay located on the South shore of the St. Lawrence estuary $\left(48^{\circ} 40^{\prime} \mathrm{N}, 68^{\circ} 00^{\prime}\right.$ W). Each animal was randomly selected with similar shell length and brought back to our field laboratory.

\section{Hemolymph collection, viability and cellularity}

Hemolymph was collected from individual animal from the posterior adductor muscle using a sterile $3 \mathrm{~mL}$ syringe with a $23 \mathrm{G}$ needle. Hemocytes viability and cellularity were determined as follows. Briefly, an aliquot of $200 \mu \mathrm{L}$ of hemolymph was mixed with $20 \mu \mathrm{L}$ of propidium iodide (stock solution $10 \mu \mathrm{g} / \mathrm{mL}^{-1}$ ) (Sigma Chemical Company, St. Louis, MO, USA)..$^{9}$ A total number of 5000 events were acquired by flow cytometry (BD Accuri ${ }^{\mathrm{TM}}$ C6 Cytometer, Becton Dickinson, San Jose, CSA, USA).

Hemocytes were defined and gated based on their forward (FSC) and right angle scatter (SSC) properties. Then, fluorescence emission of propidium iodide was collected on FL3 ( $>670 \mathrm{~nm}$ ). A total of 5000 events was acquired in the gate, for each sample, and stored in the list mode data format. The data were then analyzed once displayed as two-parameters, complexity (SSC) and cell size (FSC) then, the fluorescence (FL3) frequency distribution histogram of the hemocytes population was obtained. Viability was calculated as follow: viability $=100 \%-\%$ of dead cells (FL3 ${ }^{+}$cells). ${ }^{9}$ Ten mussels were used per drug and for the mixture as well. Cell viability was determined before and after the exposure period. Data collection and analysis were performed with BD Accuri ${ }^{\mathrm{TM}}$ C6 Software (Becton Dickinson; version 1.0.264.21). Results are expressed in percentage of viable cells.

\section{Phagocytosis}

After $3 \mathrm{~h}$ of exposure with individual drugs and mixture, yellow-green latex Fluospheres (Molecular Probes Inc., Eugene, OR, USA), with a diameter of $1.2 \mathrm{~nm}$, were added in the plates at a ratio of 1:100 (hemocytes:beads) and left in the dark at room temperature for another incubation period of $18 \mathrm{~h}$. Then, the microplates were drained and cells were resuspended and fixed with $0.5 \%$ formaldehyde. All the acquisitions were done using a BD Accuri $^{\mathrm{TM}}$ C6 Cytometer (Becton Dickinson) as described for viability with the exception that fluorescence emission of yellow-green was collected on FL1 $(533 / 30 \mathrm{~nm}) .^{9}$ Results are expressed as the percentage of hemocytes having engulfed one or more fluorescent beads (capacity) and three or more fluorescent beads (efficiency).

\section{Exposure protocol}

We tested individually a total of 4 drugs; benzoylecgonine (CAS 115732-68-8), methamphetamine (CAS 537-46-2), cocaine (CAS 5036-2) and 3-4-methylendioxyamphetamine (CAS 6292-91-7). A mixture of 8 drugs was prepared with equal concentration of oxazepam (CAS 604-75-1), diazepam (439-14-5), fentanyl (CAS 1443-54-5), norfentanyl (1609-66-1), mephedrone (CAS 1189726-22-4), 4-methylephedrine (42151-56-4), benzoylecgonine and MDMA (CAS 64057-70-1).

Since the drugs were dissolved in acetonitrile and methanol, we had to first, test the toxicity of these solvents. Hemocytes from a volume of $180 \mu \mathrm{L}$ of hemolymph from each mussel were exposed for $21 \mathrm{~h}$, at room temperature, to different concentrations of solvent, ranging from 0 to $25 \%$ (V/V) in 2 microplates. After $3 \mathrm{~h}$ of exposure, we added yellow-green latex Fluospheres and after $21 \mathrm{~h}$ of exposure, we established the concentration limit for each
Correspondence: Claude Brousseau-Fournier, ISMER-UQAR, Rimouski, Québec, Canada.

E-mail: claude.brousseau-fournier@uqar.ca

Key words: Illicit drugs; immune capacity; Mytilus edulis.

Acknowledgments: the authors would like to thank Mr. Alexandre Palardy from ISMER-UQAR, for the preparation of solutions of drugs.

Conference presentation: part of this paper was presented at ECOBIM meeting, 2015 May, Québec City, Québec, Canada.

This work is licensed under a Creative Commons Attribution NonCommercial 3.0 License (CC BYNC 3.0).

(C) Copyright C. Brousseau-Fournier et al., 2015 Licensee PAGEPress, Italy

Journal of Xenobiotics 2015; 5:5770

doi:10.4081/xeno.2015.5770

solvent that did not affect the viability and the phagocytosis.

For the drug exposures, volumes of $180 \mu \mathrm{L}$ of hemolymph from each mussel were delivered in 2 microplates for each concentration of drugs. The drugs were added for a total volume of $200 \mu \mathrm{L}$ per well. Like for solvent, we exposed for a total of $21 \mathrm{~h}$ in the dark at room temperature. After $3 \mathrm{~h}$ of exposure, yellow-green fluorescent latex Fluorospheres was added to 1 microplate. At the end of the exposure period, we tested the viability and phagocytosis. For individual drugs, the concentrations tested were $0.0,12.5,25.0,50,75$ and $100 \mu \mathrm{g} / \mathrm{L}$. For the mixture, the concentrations tested were $0.0,12.5$, and $25.0 \mu \mathrm{g} / \mathrm{L}$.

\section{Statistical analysis}

Data were analyzed with SigmaPlot ${ }^{\circledR}$ version 12.5 software (Systat Software, Inc., San Jose, CA, USA). Kruskal-Wallis analysis of variance (ANOVA) test and Dunn's Method were used to identify groups that differed significantly from control. Significance was set at $\mathrm{P} \leq 0.05$.

\section{Results}

\section{Solvants}

Acetonitrile was cytotoxic for hemocytes at concentrations of $15 \%$ (V/V) and higher, while the phagocytosis (activity and efficiency) was not affected at all by this solvent. Consequently, for drug exposure, a maximum of $10 \%$ acetonitrile was used (results not shown).

Methanol was cytotoxic only at 25\% (V/N). Phagocytic activity was not altered at all by methanol, while phagocytic efficacy was sig- 


\section{Phagocytosis and Viability}

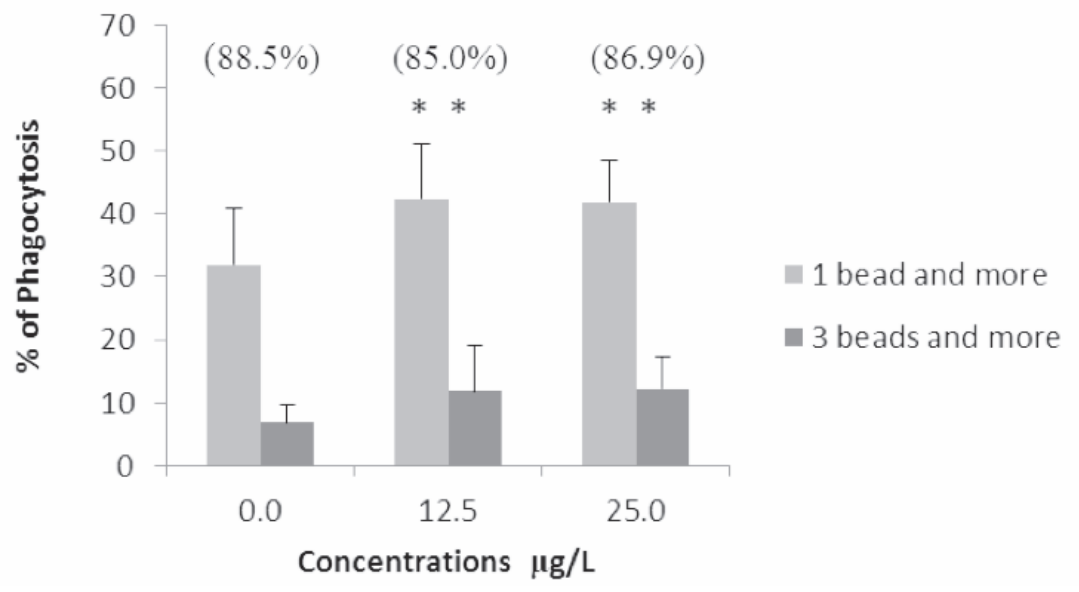

Figure 1. Percentage of viability, phagocytic activity ( 1 bead and more) and efficiency (3 beads and more) following an exposure of $21 \mathrm{~h}$. Viability was not affected while phagocytic activity and efficiency were significantly increased when compared to control. $* * \mathbf{P} \leq 0.05$.

nificantly decreased at $10 \% \quad(\mathrm{~V} / \mathrm{V})$. Consequently, for drug exposure, a maximum of $5 \%$ methanol was used (results not shown).

\section{Individual drugs and mixture}

For all individual drugs, results were pretty steady, with viability over $90 \%$ for all the concentrations tested. Similarly, for the phagocytosis, neither the activity nor the efficiency was significantly different from control at tested concentrations (data not shown).

For the mixture, the results for viability and phagocytosis are presented in Figure 1. For the viability, the percentage was not significantly different from the control at the 2 tested concentrations. However, for the phagocytosis, we have observed a significant increase of about 1.3 fold for activity and 1.6 fold for efficiency.

\section{Discussion and Conclusions}

Some studies have shown an important impact of illicit drugs on bacteria. In fact, a lot of plant-derived alkaloids seem to have antimicrobial properties that may cause a change in the bacterial fauna. In aquatic ecosystems, the bacteria are at the very bottom of the food web, thus if the composition of the bacterial fauna changes, due to the presence of illicit drugs, the whole composition of the trophic chain might be affected. ${ }^{10,11}$

Other studies have shown that fresh water invertebrates are also affected by plant-derived drugs. Those effects are due to the adaptation of these plants to the herbivorous. In other words, the alkaloid plants have developed, over time, insecticidal properties that could possibly affect invertebrates. Zebra mussel (Dreissena polymorpha) exposed to cocaine and benzoylecgonine showed oxidative stress, DNA damage and inactivation of defense properties. ${ }^{12}$ On the other hand, Elliptio complana$t a$ exposed to morphine ended up with physiological changes in tissues. ${ }^{13}$

The concentrations of individual drugs tested, were not cytotoxic for hemocytes and did not affect at all the phagocytosis. However, when mixed, drugs remained not cytotoxic but this mix has shown immunostimulative properties. Indeed, phagocytic activity and efficiency were increased by 1.3 and 1.6 fold respectively. This immunostimulatory effect is quite interesting because this type of immunomodulation is not observed very frequently compared to immunosuppression. A wide range of xenobiotics has been identified as activator of the immune system. They could globally or specifically increase immune responses such as interferon-gamma ${ }^{14}$ and beryllium ${ }^{15}$ respectively and they could be also beneficial ${ }^{16}$ or deleterious. ${ }^{15}$ In addition to drugs and metals, other classes of compounds possess also immunostimulatory properties such as pesticides, polycyclic aromatic hydrocarbons and polychlorobiphenyls ${ }^{17}$ as well as nanoparticles. ${ }^{18}$ Other experiments are needed to better characterize the immunostimulation potential of illicit drugs.

\section{References}

1. Rosi-Marshall EJ, Snow D, Bartelt-Hunt SL, Paspalof A. A review of ecological effects and environmental fate of illicit drugs in aquatic ecosystems. J Hazard Mater 2014 [Epub Ahead of Print].

2. Pal R, Megharaj M, Kirkbride KP, Naidu R. Illicit drugs and the environment: a review. Sci. Total Environ 2013;463464:1079-92.

3. Rutsch M, Rieckermann J, Lindberg RH, Phan C, Tysklind M, Larsson DGJ. Contamination of surface, ground and drinking water from pharmaceutical production. Environ Toxicol Chem 2009;28: 2522-7.

4. Kaushal SS, Groffman PM, Band LE, Elliott EM, Shields CA, Kendall C. Tracking nonpoint source nitrogen pollution in humanimpacted watersheds. Environ Sci Technol 2011;45:8225-32.

5. Munoz I, Lopez-Doval JC, Ricart M, Villagrasa M, Brix R, Geiszinger A, et al. Bridging levels of pharmaceuticals in river water with biological community structure in the Llobregat river bain (Northest Spain). Environ Toxicol Chem 2009;28: 2706-14.

6. Rosi-Marshall EJ, Kincaid D, Bechtold HA, Royer TV, Rojas M, Kelly JJ. Pharmaceuticals suppress algal growth and microbial respiration and alter bacterial communities of stream biofilms. Ecol Appl 2013;23:583-93.

7. Drury B, Rosi-Marshall EJ, Kelly JJ. Wasterwater treatment effluent reduces the abundance and diversity of benthic bacterial communities in urban and suburban rivers. Appl Environ Microbiol 2013;79:1897.

8. Brodin T, Fick J, Jonsson M, Klaminder J. Dilute concentrations of a psychiatric drug alter behavior of fish from natural populations. Science 2013;339:814-5.

9. Brousseau P, Payette Y, Tryphonas H, Blakley B, Boermans H, Flipo D, et al. Manual of immunological methods. Boca Raton, FL: CRC Press; 1998.

10. Jonsson M, Fick J, Klaminder J, Brodin T. Antihistamines and aquatic insects: bioconcentration and impacts on behavior in damselfly larvae (Zygoptera). Sci Total Environ 2014;472:108-11.

11. Radulovic NS, Blagojevic PD, StojanovicRadic ZZ, Stojanovic NM. Antimicrobial plant metabolites: structural diversity and mechanism of action. Curr Med Chem 2013;20:932-52.

12. Parolini M, Binelli A. Oxidative and genetic responses induced by $\Delta$-9-tetrahydrocannabinol $(\Delta-9-\mathrm{THC})$ to Dreissena polymorpha. Sci Total Environ 2014;468469:68-76.

13. Gagné F, André C, Gélinas M. Neurochimical effects of benzodiazepine and morphine on freshwater mussels. Comparat Biochem Physiol Part C 
2010;152:207-14

14. Schroder K, Hertzog PJ, Ravasi T, Hume DA. Interferon-gamma: an overview of signals, mechanisms and functions. J Leukocyte Biol 2004;75:163-89.

15. Newman LS, Mroz MM, Balkissoon R, Maier LA. Beryllium sensitization progresses to chronic Beryllium disease. Am J Respir Crit
Care Med 2005;171:54-60.

16. Klatzmann D, Abbas AK. The promise of low-dose interleukin-2 therapy for autoimmune and inflammatory diseases. Nature Rev Immunol 2015;15:283-94.

17. Bahadar H, Abdollahi M, Maqbool F, Baeeri M, Niaz K. Mechanistic overview of immune modulatory effects of environmen- tal toxicants. Inflamm Allergy Drug Targets 2014;13:382-6.

18. Suliman 0, Ali D, Alarifi S, Harrath AH, Mansour L, Alwasel SH, et al. Evaluation of cytotoxic, oxidative stress, proinflammatory and genotoxic effect of silver nanoparticles in human lung epithelial cells. Environ Toxicol 2015;30:149-60. 